\title{
Triplanar estimation of left atrial volume
}

\author{
Pedram Kazemian, June Baron, Kelvin Chow, Mark Haykowsky, Richard Thompson, lan Paterson* \\ From 2011 SCMR/Euro CMR Joint Scientific Sessions \\ Nice, France. 3-6 February 2011
}

\section{Introduction}

Left atrial volume (LaV) is an important predictor of outcome for many cardiovascular conditions. The most commonly used method to estimate $\mathrm{LaV}$ is the area-length (AL) biplane formula based upon LA measures from 2 and 4 chamber $(\mathrm{CH})$ views. Given the asymetrical shape of the LA, we hypothesized that a formula incorporating measures from all 3 conventional long-axis views is a more accurate method for estimating $\mathrm{LaV}$.

\section{Purpose}

The aim of this study was to assess the accuracy of AL biplane formula for $\mathrm{LaV}$ and to derive a new formula for estimating LaV based on measurements from the two, three and four $\mathrm{CH}$ views.

\section{Methods}

Consecutive atrial fibrillation (AF) patients referred for CMR to assess pulmonary veins and left atrial size prior to catheter based treatment were included. During the study period, patients without AF and minimal structural heart disease on CMR were also examined. For each patient group, a $1.5 \mathrm{~T}$ magnet was used to acquire 2,3 and $4 \mathrm{CH}$ cines in addition to an axial stack through the heart. Left atrial dimensions, width (W) and length (L), and areas (A) were measured on each of the three long axis views and the $\mathrm{LaV}$ was estimated using the AL biplane formula. The axial stack was used to calculate the true LaV by a method of disks (MoD) summation. To find the optimum formula for estimating $\mathrm{LaV}$, a full quadratic model equation was used. The regressor variables included dimensions and area of the left atrium obtained from each of the three long axis views. All calculated LaVs were compared to the true $\mathrm{LaV}$ to assess for accuracy.

University of Alberta, Edmonton, AB, Canada

\section{Results}

Left atrial measures were assessed on 97 patients, 49 with AF, 67 male with mean age of $46 \pm 15$. The LaV estimated by the AL biplane formula (mean $87.8 \pm$ $31.7 \mathrm{ml}$ ) was significantly lower than that derived from the MoD (mean $117.7 \pm 36.1 \mathrm{ml}, \mathrm{p}<0.001$ ). Using BlandAltman method, the $95 \%$ limits of agreements (LOA) were $-69.5 \mathrm{ml}$ to $9.6 \mathrm{ml}$. Our derived triplanar formula, $\mathrm{LaV}=0.628 \mathrm{X}$ Lmax X Amax, correlated better with MoD LaV $\left(R^{2}=0.79\right)$, than the AL biplanar method $\left(\mathrm{R}^{2}=0.69\right)$ and provided an unbiased estimate of the true mean $\mathrm{LaV}, 95 \% \mathrm{LOA}$ of $-33.8 \mathrm{ml}$ to $30.4 \mathrm{ml}$.

\section{Conclusions}

A triplanar formula that considers measures from all three conventional long-axis views significantly improves accuracy of LaV measurement over the AL formula.

Published: 2 February 2011

doi:10.1186/1532-429X-13-S1-P327

Cite this article as: Kazemian et al:: Triplanar estimation of left atrial volume. Journal of Cardiovascular Magnetic Resonance 2011 13(Suppl 1): P327.

Submit your next manuscript to BioMed Central and take full advantage of:

- Convenient online submission

- Thorough peer review

- No space constraints or color figure charges

- Immediate publication on acceptance

- Inclusion in PubMed, CAS, Scopus and Google Scholar

- Research which is freely available for redistribution
C 2011 Paterson et al; licensee BioMed Central Ltd. This is an open access article distributed under the terms of the Creative Commons Attribution License (http://creativecommons.org/licenses/by/2.0), which permits unrestricted use, distribution, and reproduction in any medium, provided the original work is properly cited. 